\title{
PENGARUH KUALITAS PELAYANAN, KEPERCAYAAN TERHADAP KEPUASAN NASABAH PADA CABANG BMT FAJAR METRO PUSAT
}

\author{
${ }^{1}$ Ardiansyah Japlani, ${ }^{2}$ Fitriani, ${ }^{3}$ Siti Mudawamah \\ Universitas Muhammadiyah Metro \\ Email : fitriasrin2606@gmail.com
}

\begin{abstract}
FIDUSIA
Jurnal Ilmiah Keuangan dan Perbankan

ISSN Cetak : 2621-2439

ISSN Online : 2621-2447

Kata kunci : kualitas pelayanan, kepercayaan, kepuasan nasabah.

\section{ABSTRACT}

Penelitian ini dilatarbelakangi oleh kepuasan nasabah yang merupakan sebuah tindakan nasabah untuk menggunakan produk jasa. Tujuan Penelitian ini untuk mengetahui kualitas pelayanan dan kepercayaan berpengaruh terhadap kepuasan nasabah.

Dalam penelitian ini menggunakan data primer yang dikumpulkan dengan metode explanatory research dan teknik pengumpulan data sampel berupa simple random sampling terhadap sembilan puluh delapan orang responden nasabah Cabang BMT FAJAR Metro Pusat menggunakan kuesioner dengan skala Likert pada Cabang BMT FAJAR Metro Pusat. Pengujian persyaratan instrumen yang digunakan meliputi uji validitas, uji reliabilitas. Uji normalitas, uji linieritas, uji homogenitas. Uji parsial (uji t), uji simultan (uji f), dan uji koefisien determinasi $\left(\mathrm{R}^{2}\right)$. Sebagai pengujian persyaratan analisis dan pengujian hipotesis.

Teknik analisis data yang digunakan adalah analisis regresi linier berganda. Berdasarkan hasil penelitian dengan menggunakan analisis regresi linier berganda diperoleh kualitas pelayanan berpengaruh terhadap kepuasan nasabah dan kepercayaan berpengaruh terhadap kepuasan nasabah. Kualitas pelayanan dan kepercayaan berpengaruh positif dan signifikan secara parsial maupun secara simultan.
\end{abstract}

Kata kunci : kualitas pelayanan, kepercayaan, kepuasan nasabah. 


\section{PENDAHULUAN}

Perkembangan teknologi dan informasi diera globalisasai saat ini sangat berperan penting dalam membantu kehidupan manusia. Dilihat dari segi pemenuhahannya, teknologi pada masa sekarang bukan lagi menjadi kebutuhan sekunder saja, tetapi sudah menjadi hal yang tidak bisa dilepaskan dari kehidupan manusia dalam melakukan aktivitas sehari-hari. Kamajuan teknologi dan informasi juga mendorong pesatnya pertumbuhan perekonomian yang ada di masyarakat, mendorong tingkat konsumsi masyarakat yang lebih tinggi.

Baitul Mal Wattamwil atau yang disingkat BMT merupakan lembaga keuangan non bank yang berpedoman dengan syariah islam (AL-Qur'an dan Hadist) yang bertujuan meningkatkan perekonomian masyarakat menengah kebawah. Akhir-akhir ini BMT mulai dikenal oleh insan perekonomian terutama dalam perekonomiaan islam sejak krisis ekonomi yang terjadi diindonesia. Pemberian layanan yang baik kepada para konsumen juga harus didukung dengan adanya perlengkapan sarana prasarana yang memadai, agar pelayanan yang diberikan maksimal dan memberikan kesan puas kepada konsumen atau nasabah.

Keuntungan dari pelanggan atau nasabah yang merasa puas disuatu perusahaan akan menimbulkan rasa loyalitas (kesetian) pelanggan atau nasabah, mengulang kembali mengkonsumsi produk barang atau jasa yang di tawarkan. Untuk mendapatkan keuntungan tersebut banyak yang perlu diperhatikan oleh perusahaan, yaitu: memperhatikan kualitas pelayanan, kenyamanan dan keamanan lokasi perusahaan, kemudahan transaksi, penanganan komplain atau keluhan, meningkatkan kepercayaan dan faktor lainnya yang dapat mempengaruhi kepuasan nasabah.

Tabel 1.1 Perkembangan Jumlah Nasabah Cabang BMT Fajar Metro Pusat Periode 2015-2018

\begin{tabular}{|c|c|c|}
\hline Tahun & Jumlah Nasabah & Perkembangan Jumlah Nasabah (\%) \\
\hline 2015 & 3.774 & - \\
\hline 2016 & 3.465 & $(-8,18 \%)$ \\
\hline 2017 & 4.493 & $29,67 \%$ \\
\hline 2018 & 4.939 & $9,92 \%$ \\
\hline
\end{tabular}

Sumber : Cabang BMT Fajar Metro Pusat 2019 (Data Diolah)

Berdasarkan tabel 1.1 diatas dapat dilihat bahwa jumlah nasabah mengalami peningkatan setiap tahunnya, namun pada tahun 2016 mengalami penurunan jumlah nasabah. Pada tahun 2015, jumlah nasabah sebanyak 3.774 orang dan mengalami penurunan pada tahun 2016 yang berjumlah 3.465 orang atau mengalami penurunan sebesar (-8,18\%). Namun pada tahun 2017 mengalami peningkatan yang cukup besar, dengan jumlah nasabah sebanyak 4.493 orang atau mengalami peningkatan sebesar 
29,67\%. Dan pada tahun 2018 juga mengalami peningkatan jumlah nasabah sebesar 4.939 orang artinya jumlah nasabah mengalami peningkatan sebesar 9,92\% dari tahun sebelumnya. Dengan adanya penurunan pada tahun 2016, Pihak BMT melakukan berbagai upaya untuk terus meningkatkan kualitas pelayanan dan kepercayaan dengan tujuan memberikan kepuasan yang sesuai harapan konsumen seperti lengakapnya sarana prasarana dan perusahaan tersebut amanah dalam menyimpan atau mengelola uang konsumen secara optimal dan juga akan berpengaruh pada meningkatnya jumlah nasabah yang diinginkan perusahaan

\section{KAJIAN PUSTAKA}

\section{Pengertian Manajemen Pemasaran}

Kotler dan Amstrong (2012 : 4) menyatakan bahwa yang dimkasud dengan manajemen pemasaran merupakan suatu proses untuk memberikan nilai kepada konsumen dan membangun hubungan yang erat dengan konsumen dengan cara yang menguntungkan perusahaan.

\section{Pemasaran Jasa}

Lovelock dan Wirtz (2011 : 36) menyatakan bahwa pemasaran jasa adalah bagian dari system jasa keseluruhan dimana perusahaan tersebut memiliki sebuah bentuk kontak dengan konsumennya, mulai dari pengiklanan hingga penagihan, hal itu mencakup kontak yang dilakukan pada saat penyerahan jasa.

\section{Pengertian Kualitas Pelayanan Jasa}

Kotler dan Keller (2012 : 35) menyatakan bahwa jasa adalah suatu kinerja penampilan, tidak berwujud dan cepat hilang, lebih dapat dirasakan daripada dimiliki, serta konsumen dapat berpartisipasi aktif dalam proses mengkonsumsi jasa tersebut.

\section{Faktor-faktor yang Mempengaruhi Kualitas Pelayanan Jasa}

Faktor utama yang mempengaruhi sukses tidaknya pelayanan adalah sumber daya manusianya. Artinya peranan manusia (karyawan dan pimpinan) yang melayani pelanggan merupakan faktor utama, karena hanya dengan manusialah pelanggan dapat berkomuukasi secara langsung dan terbuka, sekalipun pelayanan dapat dilakukan dengan menggunakan mesin.

Pada dasarnya pelayanan yang diberikan oleh manusia dipengaruhi oleh hal-hal berikut ini:
a) Jumlah Tenaga kerja
b) Kualitas Tenaga Kerja (pengetahuan dan keterampilan)
c) Motivasi karyawan
d) Kepemimpinan
e) Budaya Organisasi 
f) Kesejahteraan Karyawan

g) Lingkungan Kerja dan Faktor lainnya.

\section{METODE PENELITIAN}

\section{A. Jenis Penelitian}

Jenis Penelitian ini adalah penelitian kuantitatif. Menurut Sugiyono (2015 : 23) data kuantitatif adalah data yang berbentuk angka, atau data kuantitatif yang diangka kan (Scoring)

\section{Data Primer}

Data primer merupakan data yang diproleh secara langsung dari responden (nasabah) melalui wawancara dengan panduan koesioner yang ditujukan kepada nasabah yang ada pada Cabang BMT FAJAR Metro Pusat yang bersedia menjadi sampel dalam penelitian ini. Jenis pertanyaan yang digunakan dalam koesioner adalah close ended questions, yaitu bentuk pertanyaan dengan beberapa alternatif jawaban bagi responden dengan data yang dihasilkan berbenuk skala Likert, yaitu interval 1 sampai dengan 5 .

\section{Data Sekunder}

Data sekunder adalah data yang diperoleh dari sumber yang sudah ada. Data sekunder dapat berupa catatan dan dokumentasi yang dipublikasikan oleh perusahaan, misalnya absensi, gaji, laporan keuangan publikasi perusahaan, data yang diperoleh dari majalah atau brosur

\section{B. Metode}

\section{Operasional Variabel}

Operasional disini menjelaskan mengenai variabel-variabel penelitian yang digunakan penelitian ini dengan tujuan memberikan kesimpulan mengenai batasan serta ruang lingkup penelitian, dari variabel yang dianalisis meliputi:

1) Variabel $X_{1}$, Kualitas Pelayanan

a. Definisi Konseptual

Kualitas pelayanan adalah Reputasi perusahaaan berdasarkan penampilan kinerja karyawan yang diberikan untuk calon nasabah atau nasabah lama yang akan memberikan penilaian baik buruknya kinerja yang dilakukan karyawan tersebut. Kualitas pelayanan merupakan strategi yang harus dilakukan dengan baik dalam perusahaan agar memenuhi keinginan nasabah dan akan menimbulkan rasa puas. Kualitas Pelayanan bersifat tidak dapat dimiliki namun dapat dirasakan. 


\section{b. Definisi Operasional}

Kualitas pelayanan adalah Reputasi perusahaaan berdasarkan penampilan kinerja karyawan yang diberikan untuk calon nasabah atau nasabah lama yang akan memberikan penilaian baik buruknya kinerja yang dilakukan karyawan tersebut. Kualitas pelayanan merupakan strategi yang harus dilakukan dengan baik dalam perusahaan agar memenuhi keinginan nasabah dan akan menimbulkan rasa puas. Kualitas Pelayanan bersifat tidak dapat dimiliki namun dapat dirasakan. Yang diukur dengan instrumen berupa kuesioner yang berisi beberapa pertanyaan yang diisi oleh nasabah Cabang BMT FAJAR Metro Pusat, dengan indikator : Keandalan, Keresponsifan, Keyakinan, Empati dan Berwujud.

2) Variabel $X_{2}$, Kepercayaan

a. Definisi Konseptual

Kepercayaan Nasabah merupakan harapan yang dipegang nasabah atas janji yang diberikan perusahaan baik secara lisan maupun tulisan dan perusahaan harus mewujudkan janji tersebut. Dengan menjaga kepercayaan dari nasabah baru maupun lama sangat berpengaruh positif terhadap perusahaan.

b. Definisi Operasional

Kepercayaan Nasabah merupakan harapan yang dipegang nasabah atas janji yang diberikan perusahaan baik secara lisan maupun tulisan dan perusahaan harus mewujudkan janji tersebut. Dengan menjaga kepercayaan dari nasabah baru maupun lama sangat berpengaruh positif terhadap perusahaan. Yang diukur dengan instrumen berupa kuesioner yang berisi beberapa pertanyaan yang diisi oleh nasabah Cabang BMT FAJAR Metro Pusat, dengan indikator : Integritas, Kebaikan dan Kompetensi.

3) Variabel Y, Kepuasan Nasabah

a. Definisi Konseptual

Kepuasan Nasabah merupakan perasaan kecewa atau senang terhadap kinerja karyawan yang sesuai dengan harapan nasabah. Kepuasan nasabah merupakan kunci sukses tidaknya suatu perusahaan atau lembaga keuangan karena dengan adanya kepuasan nasabah akan berpengaruh positif terhadap perusahaan tersebut dan apabila nasabah tidak merasa puas atas kinerja karyawan maka akan menjadi ancaman yang sangat buruk bagi perusahaan.

b. Definisi Operasional

Kepuasan Nasabah merupakan perasaan kecewa atau senang terhadap kinerja karyawan yang sesuai dengan harapan nasabah. Kepuasan nasabah merupakan kunci sukses tidaknya suatu perusahaan atau lembaga keuangan 
karena dengan adanya kepuasan nasabah akan berpengaruh positif terhadap perusahaan tersebut dan apabila nasabah tidak merasa puas atas kinerja karyawan maka akan menjadi ancaman yang sangat buruk bagi perusahaan. Yang diukur dengan instrumen berupa kuesioner yang berisi beberapa pertanyaan yang diisi oleh nasabah Cabang BMT FAJAR Metro Pusat, dengan indikator : Harapan, Kinerja, Perbandingan, Pengalaman, Konfirmasi dan Diskonfirmasi.

\section{HASIL DAN PEMBAHASAN}

Uji instrumen penelitian dilakukan untuk mengetahui validitas (ketetapatan), reliabilitas (ketetapan) dan normalitas (kesesuaian) instrumen penelitian, sebelum digunakan selanjutnya dalam penelitian adalah yang telah memenuhi kriteria valid, reliabel, dan berdistribusi normal berdasarkan hasil uji validitas, reliabilitas, dan normalitas yang telah dilakukan dan untuk pengujiannya diproses menggunakan program SPSS versi 16. Kemudian pengujian linieritas menggunakan program Microsoft Office Excel 2007 dan analisis regresi linier berganda menggunakan SPSSversi 16.

\section{Pengujian Persyaratan Analisis}

\section{a. Uji Normalitas}

Uji Normalitas digunakan untuk mengetahui apakah populasi data berdistribusi normal atau tidak. Uji ini biasanya digunakan untuk mengukur data berskala ordinal, interval ataupun rasio. Jika analisis menggunakan metode parametik, maka persyaratan normalitas harus terpenuhi, Yaitu data berasal dari distribusi yang normal, jika data tidak berdistribusi yang normal, jika data tidak berdistribusi normal maka metode alternative yang digunakan adalah statistic non parametic. Yaitu dengan menggunakan uji lilieforis dengan melihat niilai pada Kalmogorov-Smirnov.

\section{Tests of Normality}

\begin{tabular}{|l|r|r|r|r|r|r|}
\hline & \multicolumn{3}{|c|}{ Kolmogorov-Smirnov $^{\mathrm{a}}$} & \multicolumn{3}{|c|}{ Shapiro-Wilk } \\
\cline { 2 - 7 } & Statistic & \multicolumn{1}{c|}{ df } & Sig. & Statistic & \multicolumn{1}{c|}{ Df } & \multicolumn{1}{c|}{ Sig. } \\
\hline KUALITASPELAY & .080 & 98 & .126 & .975 & 98 & .054 \\
ANAN & .051 & 98 & $.200^{*}$ & .986 & 98 & .392 \\
KEPERCAYAAN & .059 & 98 & $.200^{*}$ & .977 & 98 & .077 \\
KEPUASANNASA & & & & & & \\
BAH & & & & & & \\
\hline
\end{tabular}

a. Lilliefors Significance Correction

*. This is a lower bound of the true significance. 
Berdasarkan tabel 4.1 hasil uji normalitas variabel $\mathrm{X}_{1}, \mathrm{X}_{2}$ dan $\mathrm{Y}$ menunjukan nilai signifikan lebih besar dari 0,05 dilihat dari kolom asymp. Sig. (2-tailed), sehingga dapat dikatakan bahwa data yang diuji distribusi normal.

\section{b. Uji Linieritas}

Uji linieritas dilakukan untuk kepentingan ketepatan estimasi. Setiap estimasi biasanya di harapkan pada suatu kepastian atau kejelasan sehingga kesimpulan yang dihasilkan memiliki akurasi yang tinggi. Kriteria dalam uji linier dalam penelitian ini yaitu apabila nilai signifikansi $<0,05$ maka dikatakan bahwa data tersebut variabelnya memiliki hubungan linier. Adapun hasil uji linieritas adalah sebagai berikut :

Tabel 4.2 ANOVA Linieritas $Y$ atas $X_{1}$

ANOVA Table

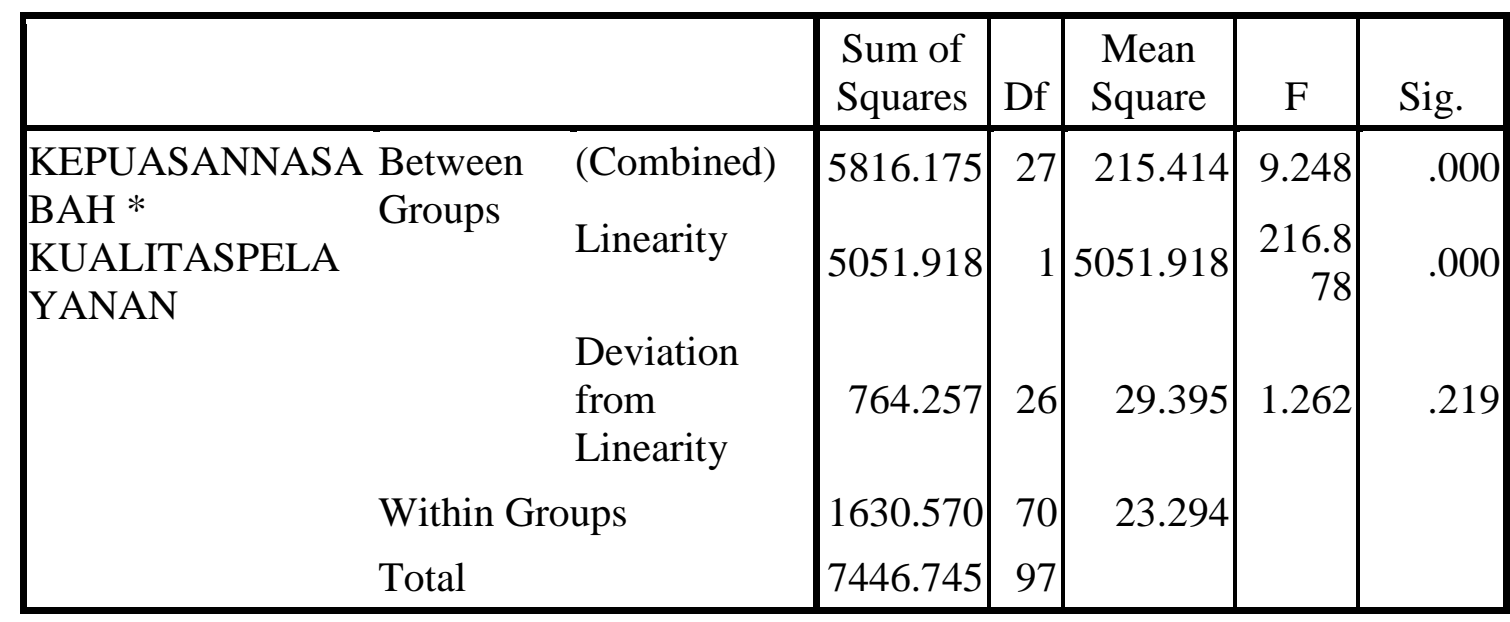

Hasil uji linieritas dapat dilihat dari output ANOVA. Dapat diketahui bahwa nilai signifikansi pada Linearity sebesar 0,000. Karena signifikan kurang dari 0,05 maka dapat disimpulkan bahwa antara variabel kepuasan nasabah (Y)dan kualitas pelayanan $\left(\mathrm{X}_{1}\right)$ terdapat hubungan yang linier. Berdasarkan output tabel 4.2 diperoleh nilai $\mathrm{F}_{\text {hitung }}=$ 1,262 sedangkan $F_{\text {tabel }}=1,67$ karena $F_{\text {hitung }}$ lebih kecil dari $F_{\text {tabel }}$ maka dapat disimpulkan bahwa terdapat hubungan yang linier secara signifikan antara variabel kepuasan nasabah (Y) dan kualitas pelayanan $\left(\mathrm{X}_{1}\right)$ 
Tabel 4.3 ANOVA Linieritas $Y$ atas $X_{2}$

ANOVA Table

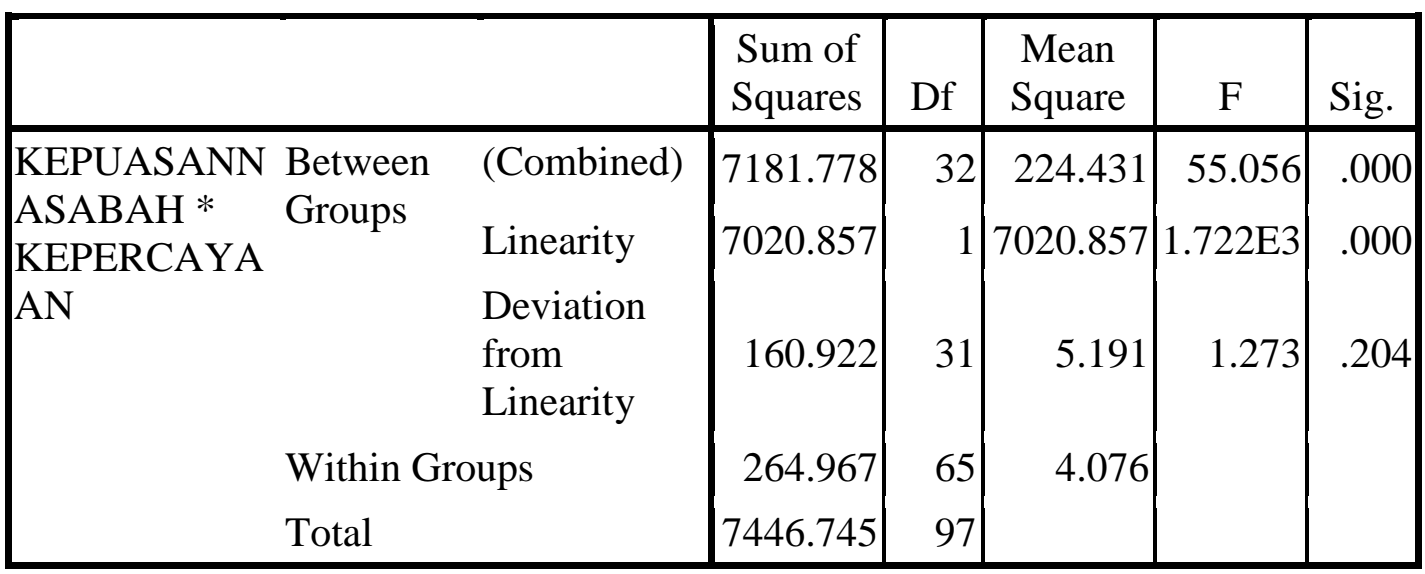

Hasil uji linieritas dapat dilihat dari output ANOVA. Dapat diketahui bahwa nilai signifikasi pada Linearity sebesar 0,000. Karena signifikan kurang dari 0,05 maka daapat disimpulkan bahwa antara variabel kepuasan nasabah (Y) dan kepercayaan $\left(\mathrm{X}_{2}\right)$ terdapat hubungan yang linier. Berdasarkan output tabel 4.3 diperoleh nilai $F_{\text {hitung }}=5,191$ sedangkan $F_{\text {tabel }}=1,63$ karena $F_{\text {hitung lebih besar dari }}$ $F_{\text {tabel }}$ maka dapat disimpulkan bahwa tidak terdapat hubungan yang linier secara signifikan antara variabel kepuasan nasabah (Y) dan kepercayaan $\left(\mathrm{X}_{2}\right)$.

\section{c. Uji Homogenitas}

Uji homogenitas dilakukan untuk menghitung bahwa data sampel berasal dari populasi yang mempunyai varians yang homogen. Adapun hasil uji homogenitas adalah sebagai berikut :

\section{Uji Homogenitas Varians $Y$ atas $X_{1}$}

Tabel4.4 Hasil Uji Homogenitas Varians $Y$ atas $X_{1}$

\section{Test of Homogeneity of Variances}

KEPUASANNASABAH

\begin{tabular}{|l|l|l|l|}
\hline Levene Statistic & df1 & df2 & Sig. \\
\hline 1.359 & 23 & 70 & .164 \\
\hline
\end{tabular}

Berdasarkan tabel 4.4 hasil uji homogenitas $\mathrm{Y}$ atas $\mathrm{X}_{1}$ menunjukkan sig 0,164 > 0,05 , sehingga skor pada variabel kualitas pelayanan $\left(X_{1}\right)$ terhadap kepuasan nasabah (Y) yang berasal dari populasi yang homogen. 


\section{Uji Homogenitas Varians $Y$ atas $X_{2}$}

Tabel 4.5 Hasil Uji Homogenitas Varians $Y$ atas $X_{2}$

Test of Homogeneity of Variances

KEPUASANNASABAH

\begin{tabular}{|l|l|l|l|}
\hline Levene Statistic & df1 & df2 & Sig. \\
\hline 4.642 & 26 & 65 & .000 \\
\hline
\end{tabular}

Berdasarkan tabel 4.5 hasil uji homogenitas $\mathrm{Y}$ atas $\mathrm{X}_{2}$ menunjukkan sig $0,000<0,05$, sehingga skor pada variabel kepercayaan $\left(\mathrm{X}_{2}\right)$ terhadap kepuasan nasabah (Y) berasal dari populasi yang tidak homogen.

\section{Diskripsi Data Hasil Quisioner}

\section{a. Distribusi Frekuensi Kualitas Pelayanan $\left(\mathbf{X}_{1}\right)$}

Data variabel kualitas pelayanan diperoleh dari hasil jawaban responden terhadap instrumen yang terdiri dari 20 butir pertanyaan yang pensekorannya menggunakan metode penskoran skala likert dengan bobot nilai 1 sampai 5 . Diperoleh rentang skor teoritik antara 20 sampai dengan 100 dan rentang skor empiris 60 sampai 96. Nilai rata-rata adalah 82,479, median 82, modus 80, varian 62,911, dan simpangan baku 7,931. Sebaran frekuensi skor variabel kualitas pelayanan $\left(\mathrm{X}_{1}\right)$ hasil tertinggi terletak pada skor 80 - 84 sebesar $28(28,571 \%)$. Hasil terendah pada skor 65 - 69 sebesar 2 (2,040\%). Berdasarkan distribusi frekuensi di atas digambarkan dalam bentuk histrogram dibawah ini:

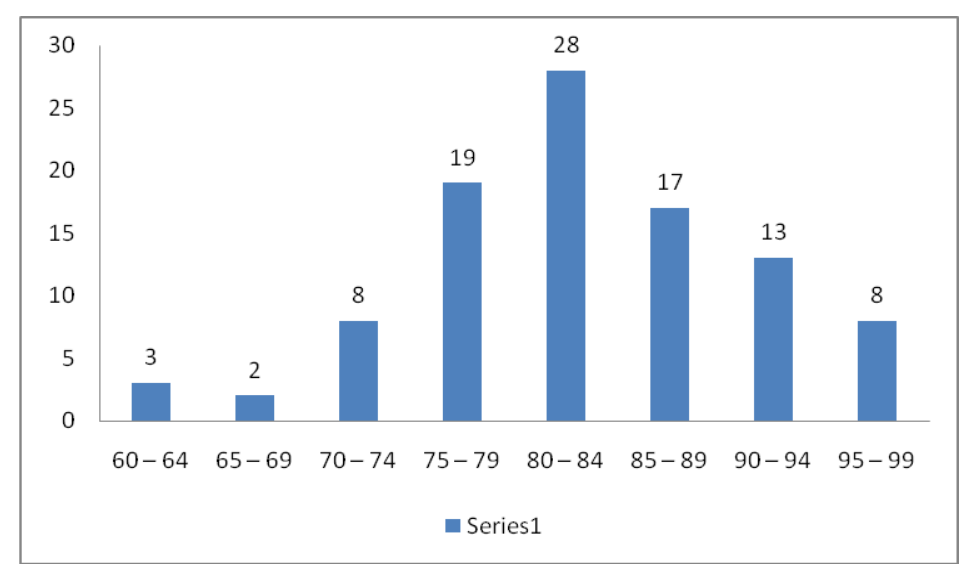

Gambar 4.2 Histrogram Skor Variabel Kualitas Pelayanan $\left(\mathbf{X}_{1}\right)$ 


\section{b. Distribusi Frekuensi Kepercayaan $\left(\mathbf{X}_{2}\right)$}

Data variabel kepercayaan diperoleh dari hasil jawaban responden terhadap instrumen yang terdiri dari 20 butir pertanyaan yang penskorannya menggunakan metode penskoran skala likert dengan bobot nilai 1 sampai 5. Diperoleh rentang skor 20 sampai dengan 100 dan rentang skor empiris antara 62 sampai 100. Nilai rata-rata adalah 82,806 , median 83 , modus 76 , varian73,085, dan simpangan baku 8,549 . Hal memperlihatkan bahwa sebaran frekuensi skor variabel kepercayaan $\left(\mathrm{X}_{2}\right)$ hasil tertinggi terletak pada skor 82- 86 sebesar $23(23,469 \%)$. Hasil terendah pada skor $62-66$ sebesar $(3,061 \%)$. Berdasarkan distribusi frekuensi diatas digambarkan dalam bentukhistrogram dibawah ini:

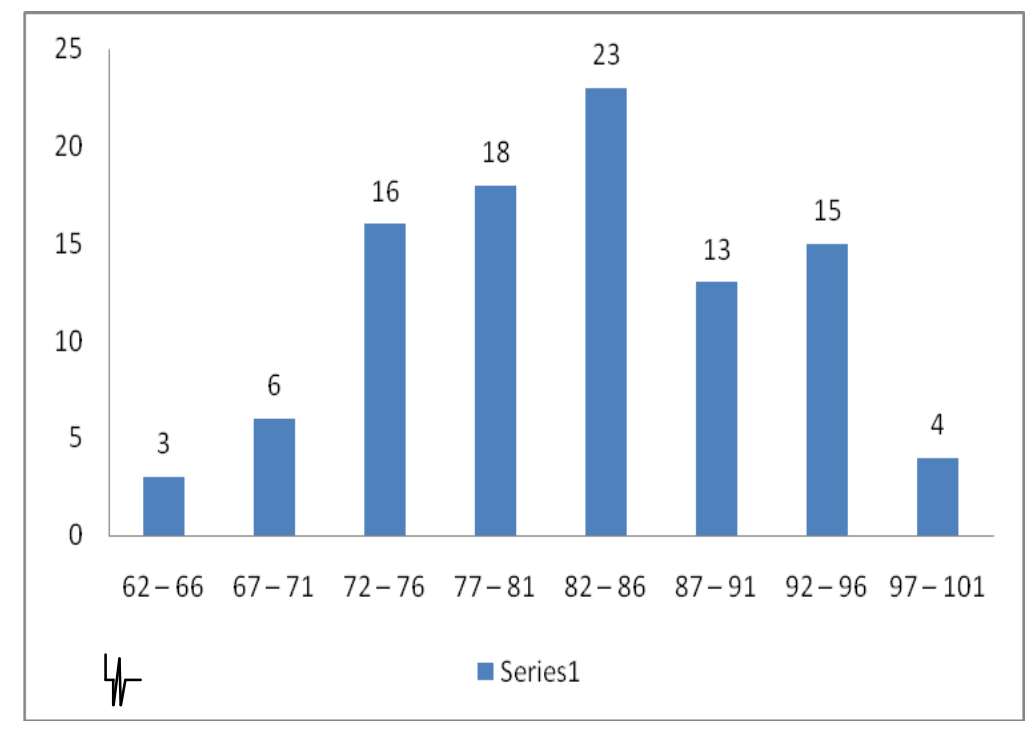

\section{Gambar 4.3 Histrogram Skor Variabel Kepercayaan $\left(\mathrm{X}_{2}\right)$}

\section{c. Distribusi Frekuensi Kepuasan Nasabah (Y)}

Data variabel kepercayaan diperoleh dari hasil jawaban responden terhadap instrumen yang terdiri dari 20 butir pertanyaan yang penskorannya menggunakan metode penskoran skala likert dengan bobot nilai 1 sampai 5. Diperoleh rentang skor 20 sampai dengan 100 dan rentang skor empiris antara 60 sampai 99. Nilai rata-rata adalah 82,948 , median 83 , modus 80 varian 76,770, dan simpangan baku 8,761. tertinggi terletak pada skor $80-84$ sebesar $25(25,510 \%)$. Hasil terendah pada skor 65- 69 sebesar $2(2,040 \%)$. Berdasarkan distribusi frekuensi diatas digambarkan dalam bentuk histrogram dibawah ini : 


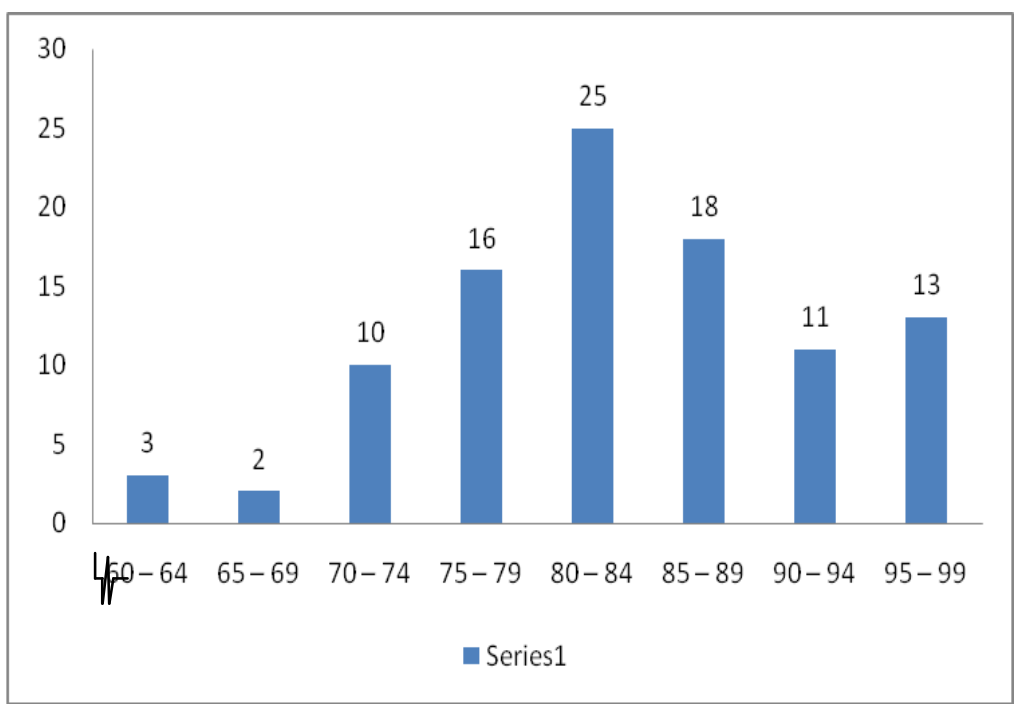

Gambar 4.4 Histogram Skor Variabel Kepuasan Nasabah (Y)

\section{Pengujian Model Analisis}

\section{a. Analisis Regresi Linier Berganda}

Analisis ini untuk memprediksi nilai dari variabel dependen apabila nilai variabel independen mengalami kenaikan atau penurunan dan untuk mengetahui arah hubungan antara variabel independen dengan variabel dependen apakah masing- masing variabel independen berhubungan positif atau negatif. Adapun hasil uji Regresi linier berganda adalah sebagai berikut:

$$
Y=\alpha+\beta_{1} X_{1}+\beta_{2} X_{2}+e
$$

Keterangan :

Y : Kepuasan Nasabah

$\alpha$ : Konstanta

$\mathrm{X}_{1}$ : Kualitas Pelayanan

$\mathrm{X}_{2}$ : Kepercayaan

$\beta_{1}$ : Koefisien regresi variabel kualitas pelayanan

$\beta_{2}$ : Koefisien regresi variabel kepercayaan

e : standard Error 
Tabel 4.9 Hasil Uji Regresi Linier Berganda

Coefficients $^{\mathrm{a}}$

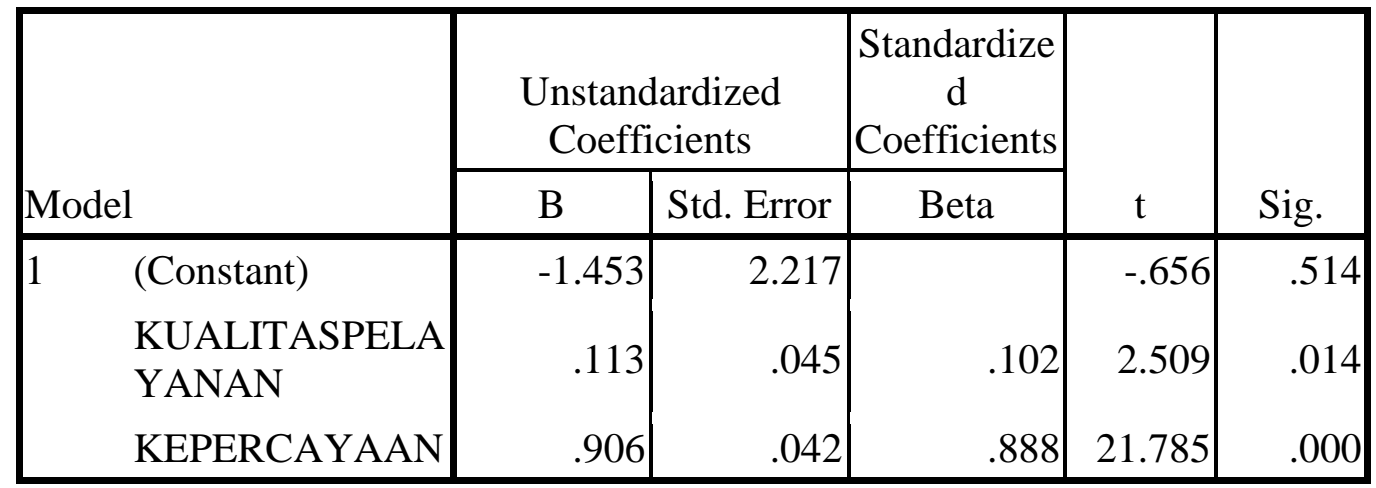

a. Dependent Variable:

KEPUASAN NASABAH

Berdasarkan hasil pengolahan data pada Tabel 4.9, dapat dirumuskan model persamaan regresi linier berganda sebagai berikut :

$$
Y=(-1,453)+0,113 X_{1}+0,906 X_{2}
$$

Berdasarkan persamaan tersebut dapat diuraikan sebagai berikut :

a. Konstanta $(\alpha)=-1,453$ Ini menunjukkan tingkat konstanta, dimana jika variabel kualitas pelayanan dan kepercayaan adalah 0 , maka kepuasan nasabah pada Cabang BMT FAJAR Metro Pusat sebesar -1,453.

b. Koefisien $\beta_{1}\left(X_{1}\right)=0,113$. Ini menunjukkan bahwa variabel kualitas pelayanan berpengarauh secara positif dan signifikan terhadap kepuasan nasabah, atau dengan kata lain, jika variabel kualitas pelayanan ditingkatkan sebesar satu satuan, maka kepuasan nasabah pada Cabang BMT FAJAR Metro Pusat akan meningkat sebesar 0,113 dengan asumsi variabel lain tetap.

c. Koefisien $\beta_{2}\left(X_{2}\right)=0,906$. Ini menunjukkan bahwa variabel kepercayaan berpengarauh secara positif dan signifikan terhadap kepuasan nasabah, atau dengan kata lain, jika variabel kepercayaan ditingkatkan sebesar satu satuan, maka kepuasan nasabah pada Cabang BMT FAJAR Metro Pusat akan meningkat sebesar 0,906 dengan asumsi variabel lain tetap.

\section{b. Uji-t}

Uji statistik t pada dasarnya menunjukkan seberapa jauh pengaruh satu variabel independen secara individual menerangkan variasi variabel independen. Uji t dengan tingkat signifikan $(\alpha)=0,05$ adalah dengan membandingkan nilai $t_{\text {hitung }}$ dengan $t_{\text {tabel }}$. Apabila $t_{\text {tabel }}<t_{\text {hitung }}$, maka Ho ditolak dan Ha diterima. Sedangkan apabila $t_{\text {tabel }}>t_{\text {hitung, }}$, maka Ho diterima dan Ha ditolak. Adapun hasil uji t adalah sebagai berikut: 
1. Kualitas Pelayanan $X_{1}$

Variabel kualitas pelayanan memiliki nilai $t_{\text {hitung }}$ sebesar 2,509 sedangkan nilai $t_{\text {tabel }}$ 1,984. Dengan demikian nilai $t_{\text {hitung }}(2,509)>t_{\text {tabel }}(1,984)$ dengan tingkat signifikansi sebesar $0,014<0,05$. Hal ini menunjukkan bahwa kualitas pelayanan berpengaruh positif dan signifikan terhadap kepuasan nasabah pada Cabang BMT FAJAR Metro Pusat, artinya jika variabel kualitas pelayanan ditingkatkan maka kepuasan nasabah akan meningkat. Maka kesimpulannya Ho ditolak dan Ha diterima.

2. Kepercayaan $\mathrm{X}_{2}$

kepercayaan memiliki nilai $t_{\text {hitung }}$ sebesar 21,785 sedangkan nilai $t_{\text {tabel }}$ 1,984. Dengan demikian nilai $t_{\text {hitung }}(21,785)>t_{\text {tabel }}(1,984)$ dengan tingkat signifikansi sebesar $0,000<0,05$. Hal ini menunjukkan bahwa kepercayaan berpengaruh positif dan signifikan terhadap kepuasan nasabah pada Cabang BMT FAJAR Metro Pusat, artinya jika variabel kualitas pelayanan ditingkatkan maka kepuasan nasabah akan meningkat. Maka kesimpulannya Ho ditolak dan Ha diterima.

\section{c. Uji-F}

Pada dasarnya uji statistik $\mathrm{F}$ menunjukkan apakah semua variabel independen (bebas) mempunyai pengaruh secara bersama- sama terhadap variabel dependen (terikat). Kriteria pengambilan keputusannya dengan tingkat signifikansi $(\alpha)=0,05$ adalah dengan membandingkan nilai $F_{\text {hitung }}$ dengan $F_{\text {tabel }}$, apabila $F_{\text {tabel }}>F_{\text {hitung, maka Ho }}$

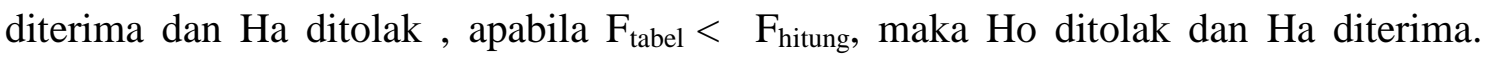
Adapun hasil uji F adalah sebagai berikut :

\section{Tabel 4.10 Hasil Uji Simultan (Uji-F)}

\section{ANOVA $^{b}$}

\begin{tabular}{|ll|l|l|l|l|l|}
\hline \multicolumn{2}{|l|}{ Model } & $\begin{array}{l}\text { Sum } \\
\text { Squares }\end{array}$ & df & $\begin{array}{l}\text { Mean } \\
\text { Square }\end{array}$ & F & Sig. \\
\hline $1 \quad$ Regression & 7047.320 & 2 & 3523.660 & 838.073 & $.000^{\mathrm{a}}$ \\
& Residual & 399.425 & 95 & 4.204 & & \\
Total & 7446.745 & 97 & & & \\
\hline
\end{tabular}

a.Predictors:(Constant),KEPERCAYAAN,KUALITASPELAYAN

AN

b. Dependent Variable: KEPUASANNASABAH

Berdasarkan tabel 4.10 dapat disimpulkan variabel kualitas pelayanan, kepercayaan secara bersama-sama berpengaruh positif dan signifikan terhadap kepuasan nasabah pada Cabang BMT FAJAR Metro Pusat. Hal tersebut dapat dilihat dari nulai $F_{\text {hitung }}$ adalah 838,073 lebih besar dari pada 2 dengan probabilitas 0,000 lebih kecil dari 0,005 dan diperoleh nilai $F_{\text {hitung }}>F_{\text {tabel }}$ yang diperoleh dengan melihat tabel $F$ dengan menggunakan 
tingkat keyakinan 95\%, $\alpha=5 \%$, nilai $d f 1=2$, dan $d f 2=(n-k-1)=98-2-1=95$. Maka nilai $F_{\text {tabel }}$ adalah sebesar 3,09. Dengan demikian diperoleh nilai $F_{\text {hitung }}>F_{\text {tabel }}(838,073>3,09)$. Berdasarkan kriteria pengujian hipotesis maka Ho ditolak dan Ha diterima.

\section{d. $\mathbf{R}^{2}$ Diterminasi}

Koefisien determinasi sering diartikan sebaga seberapa besar kemampuan semua variabel independen dalam menjelaskan varians dari variabel dependennya. Nilai koefisien determinasi berkisaran antara 0 samapai 1 . Apabila nilai koefisien determinasi mendekati 1 artinya pengaruh variabel independen terhadap variabel dependen semakin kuat, dan sebaliknya apabila nilai koefisien determinasi mendekati 0 maka pengaruh variabel independen terhadap variabel dependen semakin lemah. Adapun hasil $\mathrm{R}^{2}$ adalah sebagai berikut :

\section{Tabel 4.11 Hasil Uji $\mathbf{R}^{2}$ Diterminasi}

\begin{tabular}{|c|c|c|c|c|}
\hline \multicolumn{5}{|c|}{ Model Summary } \\
\hline Model & $\mathrm{R}$ & R Square & $\begin{array}{l}\text { Adjusted } \\
\text { Square }\end{array}$ & \begin{tabular}{l|l}
$\mathrm{R}$ & $\begin{array}{l}\text { Std. Error of the } \\
\text { Estimate }\end{array}$
\end{tabular} \\
\hline 1 & $.973^{\mathrm{a}}$ & .946 & .945 & 2.050 \\
\hline
\end{tabular}

Berdasarkan Tabel 4.11 dapat disimpulkan bahwa koefisien determinasi yang telah disesuaikan (Adjusted $R$ Square) adalah sebesar 0,945 atau 94,5\% Adjusted $R$ Square berkisaran pada angka 1-0, dengan catatan semakin besar angka Adjusted $R$ Square maka akan semakin kuat hubungan dari kedua variabel dalam model regresi. $R$ Square sebesar 0,946 berarti 94,6\% variabel kualitas pelayanan dan kepercayaan dapat dijelaskan oleh variabel kepuasan nasabah. Sedangkan 5,4\% lainnya dipengaruhi atau dijelaskan oleh variabel lain yang tidak dibahas dalam penelitian ini.

\section{Hipotesis Statistik}

Setelah dilakukan pengujian model analisis, kemudian dilakukan pengujian hipotesis untuk mengetahui pengaruh positif dan tidak positif antara variabel. Hasil keputusan terhadap seluruh hipotesis yang diajukan adalah sebagai berikut :

\section{Kualitas Pelayanan $\left(\mathrm{X}_{1}\right)$ Berpengaruh Positif dan Signifikan Terhadap Kepuasan Nasabah (Y)}

Hipotesis secara statistik dirumuskan sebagai berikut:

Ho : $\beta \mathrm{X}_{1} \mathrm{Y}, \leq 0$

$\mathrm{H}_{1}: \beta \mathrm{X}_{1} \mathrm{Y}, \geq 0$ 
Pengujian hipotesis berdasarkan hasil perhitungan koefisien $\beta$ dan $t_{\text {hitung dengan }}$ menggunakan SPSS 16 sebagaimana disajikan pada tabel 4.12 dibawah ini :

Tabel 4.12 Hasil Pengujian Pengaruh Positif dan Signifikan Kualitas Pelayanan Terhadap Kepuasan Nasabah

\begin{tabular}{|l|l|l|l|}
\hline 1. Sampel & 2. Koefisien $\beta$ & 3. $t_{\text {hitung }}$ & 4. $t_{\text {tabel }}(\alpha=0,05)$ \\
\hline 5.98 & $6.0,113$ & $7.2,509$ & $8.1,984$ \\
\hline
\end{tabular}

Sumber: Hasil Pengolahan SPSS 16

Berdasarkan hasil penujian pada tabel 4.12 Menunjukan koefisien variabel kualitas pelayanan terhadap kepuasan nasabah $\beta=0,113$ yang memiliki $t_{\text {hitung }} 2,509$ lebih besar dari nilai $t_{\text {tabel }}(\alpha=0,05)=1,984$. Karena $t_{\text {hitung }}>t_{\text {tabel }}$ maka koefisien $\beta$ positif dan signifikan. Dari temuan ini dapat disimpulkan bahwa kualitas pelayanan $\left(\mathrm{X}_{1}\right)$ berpengaruh positif dan signifikan terhadap kepuasan nasabah (Y).

\section{Kepercayaan $\left(\mathbf{X}_{2}\right)$ Berpengaruh Positif dan Signifikan Terhadap Kepuasan Nasabah (Y)}

Hipotesis secara statistik dirumuskan sebagai berikut:

Ho : $\mathrm{Bx}_{2} \mathrm{Y}, \leq 0$

$\mathrm{H}_{1}: \beta \mathrm{X}_{2} \mathrm{Y}, \geq 0$

Pengujian hipotesis berdasarkan hasil perhitungan koefisien $\beta$ dan $t_{\text {hitung }}$ dengan menggunakan SPSS 16 sebagaimana disajikan pada tabel 4.13 dibawah ini :

Tabel 4.13 Hasil Pengujian Pengaruh Positif dan Signifikan Kepercayaan Terhadap Kepuasan Nasabah

\begin{tabular}{|l|l|l|l|}
\hline Sampel & Koefisien $\boldsymbol{\beta}$ & $\mathbf{t}_{\text {hitung }}$ & $\mathbf{t}_{\text {tabel }}(\alpha=0,05)$ \\
\hline 98 & 0,906 & $\mathbf{2 1 , 7 8 5}$ & 1,984 \\
\hline
\end{tabular}

Sumber: Hasil Pengolahan SPSS 16

Berdasarkan hasil penujian pada tabel 4.13 Menunjukan koefisien variabel kepercayaan terhadap kepuasan nasabah $\beta=0,906$ yang memiliki $t_{\text {hitung }} 21,785$ lebih besar dari nilai $t_{\text {tabel }}(\alpha=0,05)=1,984$. Karena $t_{\text {hitung }}>t_{\text {tabel }}$ maka koefisien $\beta$ positif dan signifikan. Dari temuan ini dapat disimpulkan bahwa kepercayaan $\left(\mathrm{X}_{2}\right)$ berpengaruh positif dan signifikan terhadap kepuasan nasabah (Y). 


\section{Pembahasan}

Berdasarkan hasil perhitungan secara keseluruhan, maka dapat dimaknai dan dibahas sehingga memberikan informasi secara objektif sebagai berikut :

\section{Terdapat Pengaruh Positif dan Signifikan Kualitas Pelayanan Terhadap Kepuasan Nasabah}

Berdasarkan hasil penelitian menunjukkan bahwa kualitas pelayanan memiliki pengaruh positif dan signifikan terhadap kepuasan nasabah. Hal ini menunjukkan bahwa besarnya pengaruh kualitas pelayanan yang meliputi bukti fisik, kehandalan, tanggapan, jaminan dan empati yang sangat baik, maka akan meningkatkan rasa kepuasan nasabah yang tinggi dan akan meningkat pula jumlah nasabah pada Cabang BMT FAJAR Metro Pusat. Faktor kualitas pelayanan yang paling mempengaruhi kepuasan nasabah yaitu bukti fisik dan jaminan oleh karena itu Cabang BMT FAJAR harus dapat memepertahankan dan meningkatkan faktor tersebut, dan yang kurang mempengaruhi adalah faktor tanggapan oleh karena itu harus diperbaiki. Kualitas pelayanan secara parsial berpengaruh terhadap kepuasan nasabah, besarnya pengaruh kualitas pelayanan terhadap kepuasan nasabah dapat dilihat dari hasil uji t yaitu hasil dari penelitian menunjukkan bahwa kualitas pelayanan memiliki nilai $t_{\text {hitung }} 2,509$ sedangkan nilai $t_{\text {tabel }}$ 1,984. Dengan demikian nilai $t_{\text {hitung }}(2,509)>t_{\text {tabel }}(1,984)$ dengan tingkat signifikansi sebesar 0,014 $<0,05$. Hal ini menunjukkan bahwa kualitas pelayanan berpengaruh positif dan signifikan terhadap kepuasan nasabah pada Cabang BMT FAJAR Metro Pusat. Artinya jika variabel kualitas pelayanan ditingkatkan maka kepuasan nasabah akan meningkat. Maka kesimpulannya Ho ditolak dan Ha diterima.

\section{Terdapat Pengaruh Positif dan Signifikan Kepercayaan terhadap Kepuasan} Nasabah

Berdasarkan hasil penelitian menunjukkan bahwa kepercayaan memiliki pengaruh positif dan signifikan terhadap kepuasan nasabah. Hal ini menunjukkan bahwa besarnya pengaruh kepercayaan yang meliputi kebaikan, itegritas (prinsip) dan kompetensi (kemampuan) yang sangat baik dari nasabah, maka akan meningkatkan rasa kepuasan nasabah yang tinggi dan akan meningkat pula jumlah nasabah pada Cabang BMT FAJAR Metro Pusat. Faktor kepercayaan yang sangat berpengaruh yaitu kompetensi dan prinsip, sedangkan yang kurang berpengaruh yaitu kebaikan oleh karena itu harus diperbaiki. Kepercayaan secara parsial berpengaruh terhadap kepuasan nasabah, besarnya pengaruh kepercayaan terhadap kepuasan nasabah dapat dilihat dari hasil uji t yaitu hasil dari penelitian menunjukkan bahwa kepercayaan memiliki nilai $t_{\text {hitung }} 21,785$ sedangkan nilai $t_{\text {tabel }} 1$,984. Dengan demikian nilai $t_{\text {hitung }}(21,785)>t_{\text {tabel }}$ $(1,984)$ dengan tingkat signifikansi sebesar $0,000<0,05$. Hal ini menunjukkan bahwa kepercayaan berpengaruh positif dan signifikan terhadap kepuasan nasabah pada Cabang BMT FAJAR Metro Pusat. Artinya jika variabel kepercayaan ditingkatkan 
maka kepuasan nasabah akan meningkat. Maka kesimpulannya Ho ditolak dan Ha diterima.

\section{Terdapat Pengaruh Positif dan Signifikan antara Kualiatas Pelayanan dan Kepercayaan Terhadap Kepuasan Nasabah}

Hasil penelitian menemukan bahwa kualitas pelayanan dan kepercayaan berpengaruh terhadap kepuasan nasabah. Hal ini menunjukan bahwa secara simultan atau bersama- sama mempunyai pengaruh yang signifikan terhadap kepuasan nasabah. Besarnya pengaruh kualitas pelayanan dan kepercayaan dapat dilihat dari hasil uji $\mathrm{F}$ yaitu dari nilai $F_{\text {hitung }}$ adalah 838,073 lebih besar dari pada 2 dengan probabilitas 0,000 lebih kecil dari 0,05 dan diperoleh nilai $F_{\text {hitung }}>F_{\text {tabel }}$ yang diperoleh dengan melihat tabel $\mathrm{F}$ dengan menggunakan tingkat keyakinan $95 \%, \alpha=5 \%$, nilai $d f 1=2$, dan $d f 2=$ $(n-k-1)=98-2-1=95$. Maka nilai $F_{\text {tabel }}$ adalah sebesar 3,09. Dengan demikian diperoleh nilai $F_{\text {hitung }}>F_{\text {tabel }}(838,073>3,09)$.. Artinya jika variabel kualitas pelayanan dan kepercayaan ditingkatkan maka kepuasan nasabah akan meningkat. Maka kesimpulannya Ho ditolak dan Ha diterima.

\section{KESIMPULAN}

Berdasarkan hasil analisis pembahasan variabel kualitas pelayanan dan kepercayaan terhadap kepuasan nasabah pada Cabang BMT FAJAR Metro Pusat maka dapat disimpulkan sebagai berikut :

1. Kualitas pelayanan berpengaruh positif dan signifikan terhadap kepuasan nasabah. Dalam penelitian ini faktor kualitas pelayanan yang meliputi bukti fisik, keandalan, tanggapan, jaminan dan empati yang sangat perpengaruh dalam meningkatnya kepuasan nasabah. Apabila Cabang BMT FAJAR Metro Pusat memiliki kualitas pelayanan yang sangat baik, maka kepuasan nasabah akan meningkat. Jika Cabang BMT Fajar melakukan peningkatan terhadap faktor tersebut maka akan meningkatkan rasa kepuasan nasabah yang tinggi dan akan meningkat pula jumlah nasabah pada Cabang BMT FAJAR Metro Pusat.

2. Kepercayaan berpengaruh positif dan signifikan terhadap kepuasan nasabah. Dalam penelitian ini faktor kepercayaan yang meliputi kebaikan, itegritas (prinsip) dan kompetensi (kemampuan) yang sangat berpengaruh dalam meningkatnya kepuasan nasabah. Apabila Cabang BMT FAJAR Metro Pusat memiliki kepercayaan yang sangat baik dari nasabah, maka kepuasan nasabah akan meningkat. Jika Cabang BMT Fajar melakukan peningkatan terhadap faktor tersebut maka akan meningkatkan rasa kepuasan nasabah yang tinggi dan akan meningkat pula jumlah nasabah pada Cabang BMT FAJAR Metro Pusat. 
3. Kualitas pelayanan dan kepercayaan secara bersama- sama berpengaruh positif dan signifikan terhadap kepuasan nasabah. Apabila Cabang BMT FAJAR Metro Pusat memiliki kualitas pelayanan dan kepercayaan yang sangat baik, maka kepuasan nasabah akan meningkat. Jika Cabang BMT Fajar melakukan peningkatan terhadap kualitas pelayanan dan kepercayaan maka akan meningkatkan rasa kepuasan nasabah yang tinggi dan akan meningkat pula jumlah nasabah pada Cabang BMT FAJAR Metro Pusat.

\section{DAFTAR PUSTAKA}

Achmad, Buchori., Djaslim Saladin. (2010). Manajemen Pemasaran (Edisi Pertama). Bandung. CV. Linda Karya

Amstrong, Gary \& Philip, Kotler. (2012) Dasar- Dasar Pemasaran. Jilid I. Ahli Bahasa Alexander Sindoro dan Benyamin Molan. Jakarta: Penerbit Prenhalindo.

Anderson, James. C. And James A. Naurus. (1990), A Model of Distributor Firm and Manufacturer Firm Working Partnerships. Journal of Marketing, Vol.54, January, pp 42-58.

Arikunto, Suharsimi , 2006. Prosedur Penelitian : Suatu Pendekatan Praktik. Cetakan Keenam (Revisi). Jakarta : Rineka

C. Mowen, John. Michael Minor. 2002. Prilaku Konsumen. Jakarta. Erlangga

C. Mowen, John. Michael Minor. 2002. Prilaku Konsumen. Jakarta. Erlangga

Don Peppers, Marta Rogers. (2004).”Managing Customers Relationship” Canada: willey.

Dwi Aryani dan Febrina Rosnita. Pengaruh Kualitas Layanan Terhadap Kepuasan Pelanggan dan Membentuk Loyalitas Pelanggan.

Dwi Aryani dan Febrina Rosnita. Pengaruh Kualitas Layanan Terhadap Kepuasan Pelanggan dan Membentuk Loyalitas Pelanggan.

Egel et al. (2010). Prilaku Konsumen. Edisi keenam, jilid l. Jakarta: Binarupa Aksara.

Egel et al. (2010). Prilaku Konsumen. Edisi keenam, jilid l. Jakarta: Binarupa Aksara.

Erik Siswoyo. Analisis pengaruh kualitas pelayanan kepercayaan dan kepuasan nasabah terhadap loyalitas nasabah pada PT Bank Jateng Pemuda Semarang.

Erik Siswoyo. Analisis pengaruh kualitas pelayanan kepercayaan dan kepuasan nasabah terhadap loyalitas nasabah pada PT Bank Jateng Pemuda Semarang.

Fandy,Tjiiptono,(2011), Pemasaran Jasa, Bayumedia,Malang.

Fidiyanti, Irma.skripsi.Pengaruh Kualitas Layanan Atm Banking Terhadap Kepuasan Nasabah Pada Bank Syariah Mandiri Kcp Perak

Priansa, Donni Juni. 2017. Perilaku Konsumen dalam Persaingan Bisnis Kontemporer. Bandung: ALFABETA.

Rawlins, Brand L. (2007). Trust and PR Pratice. 
Solomon, Michael R and Nancy J. Rabolt. (2004). Consumer Behaviorin in Fashion. Pearson Education In. London

Yin,Yee and T.M. Faziharudean.2010. Factors Affecting Customer Loyality of Using Internet Banking in Malaysia. Journal of Electronic Banking Systems Faculty of Business and Accoutanc. University of Malaya 